\title{
Design, synthesis, biological evaluation and molecular docking of 1,7-dibenzyl substituted theophylline derivatives as novel BRD4-BD1 selective inhibitors
}

\author{
Ying-Jie Chang \\ Zhengzhou University \\ Jin-Ge Zhang \\ Zhengzhou University \\ Shuang-Shuang Yang \\ Zhengzhou University \\ Wan-Ying Lu \\ Zhengzhou University \\ Li-Na Ding \\ Zhengzhou University \\ Yi-Chao Zheng \\ Zhengzhou University \\ wen li ( 584508809@qq.com ) \\ Zhengzhou University
}

\section{Research Article}

Keywords: BRD4, Theophylline derivatives, BD1 selectivity, Molecular docking

Posted Date: February 12th, 2021

DOI: https://doi.org/10.21203/rs.3.rs-212192/v1

License: (c) (i) This work is licensed under a Creative Commons Attribution 4.0 International License. Read Full License 


\section{Abstract}

Bromodomain-containing protein 4 ( BRD4), an epigenetic reader, has been recognized as a target with therapeutic potential in several types of cancer and cardiovascular diseases. In this study, a series of 1,7dibenzyl substituted theophylline derivatives were synthesized and their BRD4 inhibitor activities were evaluated. Most of the compounds showed detectable activities with IC 50 values in the range of 2.51$10.50 \mu \mathrm{M}$. Therein, compound $6 \mathrm{e}$ showed significant selectivity for two bromodomains of BRD4, the inhibition of BD1 ( IC $50=2.51 \mu \mathrm{M}$ ) was 20 times greater than that of BD2 (IC $50>50 \mu \mathrm{M})$. Similarly, compounds $6 b-6 d, 6 f, 6 j$ and 8 a also displayed favorable BRD4-BD1 selectivity. In addition, molecular docking of compound 6e was performed to predict conceivable binding patterns of it with BRD4, prompting residue lle146 might be crucial to the observed selectivity of BRD4-BD1. These findings will be of great value and significance for the development of novel BRD4-BD1 inhibitors.

\section{Full Text}

Due to technical limitations, full-text HTML conversion of this manuscript could not be completed. However, the manuscript can be downloaded and accessed as a PDF.

\section{Figures}


$\mathbf{A}$

Pan-BRD4 Inhibitors<smiles>Cc1sc2c(c1C)C(c1ccc(Cl)cc1)=N[C@@H](CC(=O)Nc1ccc(O)cc1)c1nnc(C)n1-2</smiles>

OTX-015

Phase I clinical trial Phase II clinical trial<smiles>Cc1noc2c1-c1ccccc1C(CC(N)=O)=NC2c1ccc(Cl)cc1</smiles>

CPI-0610

Phase I clinical trial Phase II clinical trial<smiles>CCNC(=O)C[C@@H]1N=C(c2ccc(Cl)cc2)c2cc(OC)ccc2-n2c(C)nnc21</smiles>

I-BET762 Phase I clinical trial

BRD4-BD1 Inhibitors<smiles>CCCCc1c(C)nc2nc(SCc3nc4c(c(=O)[nH]c(=O)n4CCCC)n3CC)nn2c1C</smiles>

$\mathbf{A}$<smiles>COc1ccc(NC(=O)c2ccc(NC3=C(C)C(=O)CC3)c(Cl)c2)cc1</smiles>

MS402<smiles>CCS(=O)(=O)Nc1ccc(Oc2ccc(F)cc2F)c(-c2cn(C)c(=O)c3[nH]ccc23)c1</smiles>

ABBV-075 Phase I clinical trial<smiles>COc1ccccc1S(=O)(=O)Nc1ccc2c3c(cc(-n4cnc(C)c4)nc13)C(=O)N2C</smiles>

LT052

\section{BRD4-BD2 Inhibitors}<smiles>COc1cc(OC)c2c(=O)[nH]c(-c3cc(C)c(OCCO)c(C)c3)nc2c1</smiles>

RVX-208

Phase II clinical trial Phase III clinical trial<smiles>CCNC(=O)c1cc2c(-c3cc(C(C)(C)O)ccc3Oc3c(C)cc(F)cc3C)cn(C)c(=O)c2[nH]1</smiles>

ABBV-744

Phase I clinical trial<smiles>CNC(=O)c1cc(C(=O)N[C@H]2C[C@H]3COC[C@H]23)cc2c1O[C@H](CF)[C@H]2c1ccccc1</smiles>

GSK973

Figure 1

(A) Structures of typical BRD4 inhibitors 


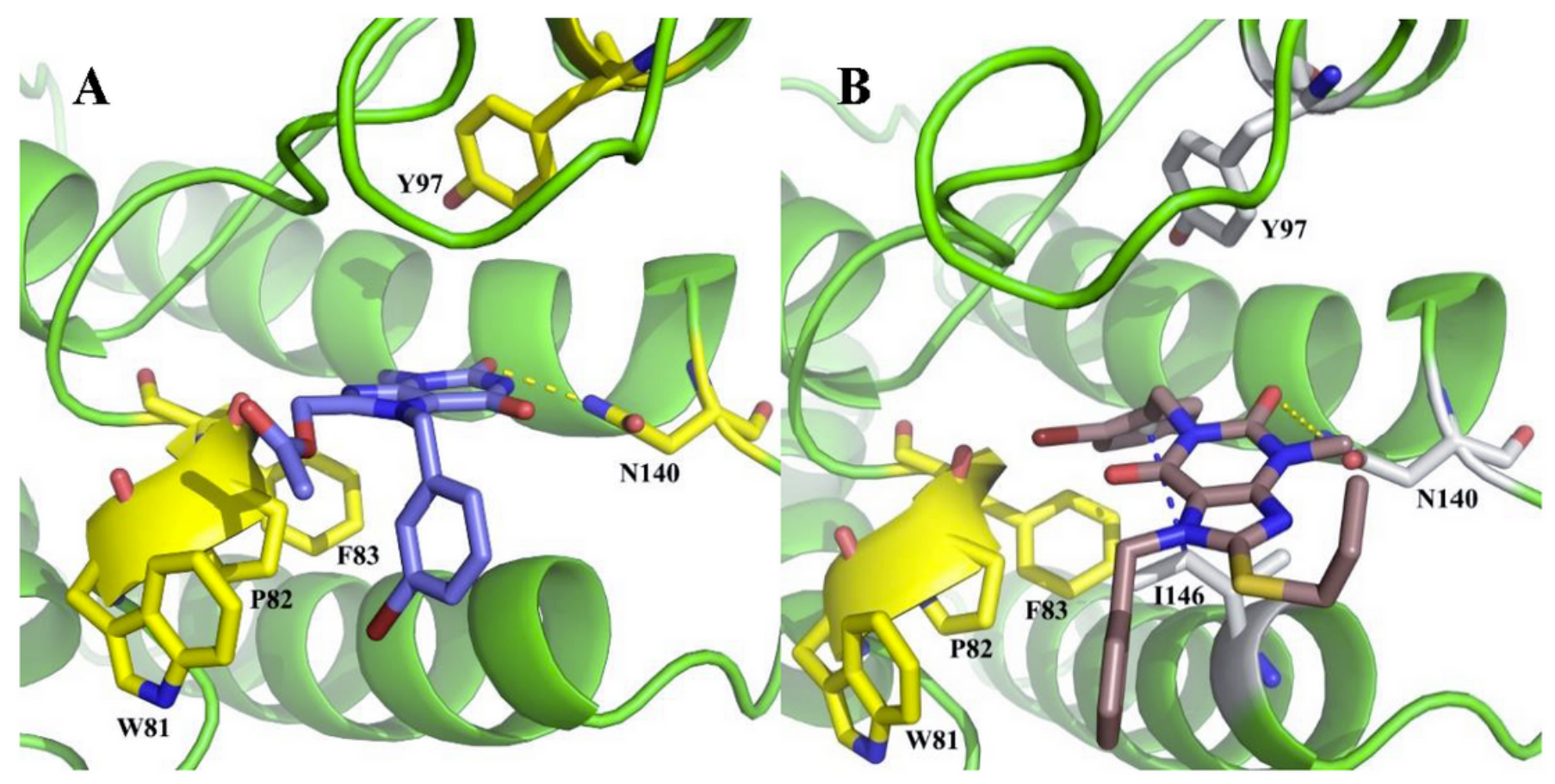

Figure 2

(A) Docking conformation of compound 3a with BRD4-BD1, compound 3a in blue violet; (B) Docking conformation of compound 8a with BRD4-BD1, compound 8a in coffee 



\section{Figure 3}

(A) Docking conformation of compound 6b with BRD4-BD1, 6b in pink, hydrogen bonds in yellow dotted lines, $\pi-\mathrm{H}$ and stacking interactions in bule dotted lines; (B) Docking conformation of compound $6 \mathrm{e}$ with BRD4-BD1, 6e in orange; (C) Docking conformation of compound 6d with BRD4-BD1, compound 6d in azure; (D) Docking conformation of compound 6c with BRD4-BD1, compound 6c in yellow; (E) Docking conformation of compound 6e with BRD4-BD2, compound 6e in orange 


\section{Supplementary Files}

This is a list of supplementary files associated with this preprint. Click to download.

- Scheme1.png

- Scheme2.png

- GraphicalAbstract.png 